\title{
Spirituality and religiosity for the transcendence of the elderly being
}

\author{
Espiritualidad y religiosidad para la trascendencia del ser anciano \\ Espiritualidade e religiosidade para a transcendência do ser idoso
}

Raúl Fernando Guerrero-Castañeda'
ORCID: 0000-0003-3996-5208

Tânia Maria de Oliva Menezes" ORCID: 0000-0001-5819-0570

Marta Lenise do Prado"' ORCID: 0000-0003-3421-3912

Jonathan Alejandro Galindo-Soto ORCID: 0000-0001-6351-8681

'Universidad de Guanajuato. Celaya, Guanajuato, México.

"Universidade Federal da Bahia. Salvador, Bahia, Brazil.

"'Universidade Federal de Santa Catarina. Florianópolis, Santa Catarina, Brazil.

How to cite this article:

Guerrero-Castañeda RF, Menezes TMO, Prado ML, Galindo-Soto JA. Spirituality and religiosity for the transcendence of the elderly

being. Rev Bras Enferm. 2019;72(0):259-65 doi: http://dx.doi.org/10.1590/0034-7167-2018-0840

Corresponding Author:

Raúl Fernando Guerrero-Castañeda

E-mail: ferxtom@hotmail.com

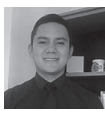

Submission: 10-28-2018 Approval: 05-28-2019

\section{ABSTRACT}

Objective: to understand the life experiences that favor transcendence of the elderly being Method: a qualitative phenomenological hermeneutic study, in two groups of elderly coexistence. The selection of participants was by intentional sampling: 11 elderly, achieving theoretical saturation. Data collection was carried out through a phenomenological interview with a detonating question. Ethical principles of the General Health Law in health research were fulfilled. Analysis with Heideggerian hermeneutic circle was performed. Results: unity of meaning on the consciousness of a higher power for transcendence is highlighted, where spirituality and religiosity are resources of the elderly for strength, feel protected, overcome difficult situations and reach fullness; both favor the understanding of their historicity by manifesting enlightenment. Final considerations: transcendence of the elderly being is favored with spirituality and the experiences of their daily life are imbued with a spiritual and religious relationship that give meaning to their existence.

Descriptors: Aged; Spirituality; Religion; Nursing; Nursing Philosophy.

\section{RESUMEN}

Objetivo: comprender las experiencias de vida que favorecen la trascendencia del ser anciano. Método: estudio cualitativo fenomenológico hermenéutico, en dos grupos de convivencia de ancianos. La selección de participantes fue por muestreo intencionado: 11 ancianos, logrando la saturación teórica. Recolección de datos a través de entrevista fenomenológica con una pregunta detonadora. Se cumplieron principios éticos de Ley General de Salud en Investigación para la Salud. Análisis con círculo hermenéutico heideggeriano. Resultados: destacó unidad de significado sobre la consciencia de un poder superior para la trascendencia, donde espiritualidad y religiosidad son recursos del anciano para fortaleza, sentirse protegido, superación de situaciones difíciles y alcanzar la plenitud; ambas favorecen la comprensión de su historicidad manifestando iluminación. Consideraciones finales: la trascendencia del ser anciano se favorece con la espiritualidad, las experiencias de su cotidiano están impregnadas de una relación espiritual y religiosa que dan sentido a su existencia.

Descriptores: Anciano; Espiritualidad; Religión; Enfermería; Filosofía en Enfermería.

\section{RESUMO}

Objetivo: compreender as experiências de vida que favorecem a transcendência do ser idoso. Método: estudo qualitativo, fenomenológico hermenêutico, em dois grupos de convivência de idosos. A seleção dos participantes foi por amostragem intencional: 11 idosos, atingindo saturação teórica. Coleta de dados através de uma entrevista fenomenológica com uma questão detonadora. Foram cumpridos ss princípios éticos da Lei Geral de Saúde em pesquisa em Saúde. Análise com círculo hermenêutico Heideggeriano. Resultados: destacou-se a unidade de significado sobre a consciência de um poder superior para a transcendência, onde a espiritualidade e a religiosidade são recursos dos idosos para a força, se sentir-se protegido, superação de situações difíceis e atingir a plenitude; ambas favorecem a compreensão de sua historicidade manifestando a iluminação. Considerações finais: a transcendência do ser idoso é favorecida pela espiritualidade, as experiências de sua vida cotidiana são imbuídas de um relacionamento espiritual e religioso que dá sentido à sua existência.

Descritores: Idoso; Espiritualidade; Religiosidade; Enfermagem; Filosofia em Enfermagem. 


\section{INTRODUCTION}

Currently, there is a noticeable increase in the elderly population worldwide, which is reflected in an increase in the older population, considered to be an older adult in relation to the chronological age of 60 years or older. Mexico is not the exception, because the increase of this population group also lives ${ }^{(1)}$, which puts into discussion if the years of life are lived with a good quality of health, so it is imperative that aging is visualized from a perspective of attention and care that favors living it fully ${ }^{(2)}$.

There is a variety in the way in which aging and old age are lived, this depends on sociocultural characteristics where the elderly has developed, sometimes it is marked by deterioration. However, old age must be lived with fullness, life satisfaction and with a sense of optimal quality of life $\mathrm{e}^{(3)}$.

Each elder experiences a type of old age, their experiences and experiences are unique, so that if this is satisfactory, there is a wealth of lived experiences that have favored this vital path, so it is possible to access them and understand from a referential phenomenological the way traveled.

Phenomenologically, from Heidegger's referential, these experiences, understood from their main actors, form part of the transcendence of being. Transcendence is manifested by a sense of maximum fullness in the being, a sense of joy, communication and understanding of the sense of life of the elderly, which reflects an old age lived in a satisfactory, successful and full way ${ }^{(4)}$.

The experiences lived throughout the life cycle of the elderly are a reference to apprehend the world and the understanding of the human being thrown into that world, is the clear experience lived in various settings that will make up a particular phenomenon ${ }^{(5)}$. Transcendence evokes that understanding of the elder about himself, a being thrown into the world facing different life experiences, which may converge to understand the phenomenon of transcendence of being from the unique approach of each human being ${ }^{(6)}$.

Frank $\left.\right|^{(7)}$ conceives transcendence as essence of vital values, the encounter of a sense, a type of spiritual connection, that surrounds the harmony, the nature, the sense of fulfillment, of well-being and of the highest human values. When this search for transcendence is favored, people can express fullness, joy and vital satisfaction, it is a phenomenon that the nurse can promote by having a holistic and spiritual vision of the human beings that care for $^{(8-9)}$.

Heidegger in his existentialist phenomenology, stresses that transcendence is a complex phenomenon in the human being, evokes the understanding of oneself in a given moment of life in temporality ${ }^{(10)}$. This self-understanding evokes various ways of taking care of oneself in order to transcend. In this way, authors point out that spirituality is a part of the human being, which is accentuated with old age due to the approach to death, which is why religious practices tend to increase with age ${ }^{(11-12)}$, standing out as a form of personal care.

Spirituality involves the awareness of a higher power and a relationship of harmony, peace and tranquility, a way of understanding oneself and the manifestation of personal fulfillment; whereas religiosity involves the practice of beliefs and spirituality itself in a given dogma ${ }^{(13-14)}$. Both are sources of well-being for the elderly and are found throughout life giving a sense of what is lived day by day ${ }^{(15-16)}$.

\section{OBJECTIVE}

To understand the life experiences that favor the transcendence of the elderly.

\section{METHOD}

\section{Ethical aspects}

The study complied with the criteria of scientific rigor for qualitative research ${ }^{(17)}$. The project was approved by the Research Committee of the Universidad de Guanajuato and complied with the ethical criteria of the General Health Law, the Helsinky Declaration and CIOMS Recommendations. The Free and Informed Consent Term of participants was provided and obtained by informing them of the project and their participation, anonymity was taken care of by giving them fictitious Sanskrit names by considering a key word that the interviewer identified in the participant.

\section{Type of study}

This is a qualitative study, with a hermeneutic phenomenological approach, using as a philosophical reference the hermeneutic phenomenology of Martin Heidegger ${ }^{(6)}$. This study was guided by the tool COREQ ${ }^{(18)}$.

\section{Study setting}

The study setting was two groups of elderly cohabitation in the community. One is a group of retirees who meet periodically to coexist and carry out various recreational activities, the other group is composed of various groups in a day gerontological center. Both groups of elders come to them to live together, so they are not institutionalized.

\section{Study participants}

For selection of participants, the criteria were: men and women over 60 years old and who stated that they felt full in the present stage of old age, an intentional type sampling was used ${ }^{(19-21)}$. This was first determined by an approach to the study setting that consisted of knowing the elders of the groups, were informal visits, dynamics known as approach to the study setting, in order to enter the stage. At a certain point they were asked if they felt full in this stage of old age, that question was selected because the fullness is the manifestation of transcendence and it was more understandable for them. Those who answered affirmatively were invited to participate in the study, were made aware of the purpose of the study and proceeded with the informed consent and general information of their participation. A sample of 11 elders was obtained that was achieved when reaching the theoretical saturation and this was achieved when converging different units of meaning to understand transcendence.

\section{Collection and organization of data}

The selected elders participated in the phenomenological interview ${ }^{(21)}$ by means of a triggering question: "Tell me, what 
experiences in your life make you feel full today?". The phenomenological interview allowed to penetrate into the subjectivity of being and allowed him to reveal himself through his historicity. The interviews were conducted from May to August 2016 and their duration was between 50 and 140 minutes. These were audio-recorded with the authorization of participants and carried out by the main investigator in the space in which participants expressed feeling comfortable. In the gerontological center there was a place to perform them, in the group of retirees participants decided the most comfortable place to carry out the interview.

\section{Data analysis}

All the interviews were faithfully transcribed by the main researcher in Microsoft Word and the information was treated in Excel Tables. The analysis was of artisanal type through the hermeneutic circle of Heidegger that includes precomprehension (approach to the phenomenon in the speeches and literature: ontic vague understanding); understanding (ontological) and interpretation (giving meaning to the units in the light of ontology) $)^{(22-23)}$.

\section{RESULTS}

In relation to the characteristics of participants, they were between 60 and 78 years old, the majority were women (9), with a degree (7), retired (6) and were Catholics (11).

In the speeches of participants the unity of meaning on the consciousness of a higher being for transcendence is appreciated, which includes two significant themes: spirituality and religiosity. The elder expresses the consciousness of a divine power, something elevated, metaphysical, whose name is god, recognizes that this power has accompanied him in his vital transit, sustains him, gives support, encouragement and strength. That god accompanies him and gives him the necessary strength to face adversity, as expressed in the following speeches:

All those things I had to overcome [...] I tell you, I find myself in holy peace with God. (Madhavi)

I had a respiratory arrest [...] I feel full because I recovered thanks to God and acupuncture, well first God then acupuncture. (Naidu)

It can be seen in the speeches that there is a clear difference between religion and spirituality, a remarkable clarification has been made between both, some beliefs teach that spirituality is a way for the human being to find himself.

The elder can be spiritual rather than religious as expressed by Omana that referred to believe in God, but not be in the church, she conceptualizes the idea of God:

I believe in God, but I'm not one of those who goes to church [...] the economic issue is not painful for me because l'm still standing, I'm healthy, which I thank God. (Omana)

In contrast, Karuna manifests to be in a specific group where they carry out practices such as prayers, songs, meditation; this corresponds to both religion and religiosity, the latter is conceived as the firm and convincing practice of religion.
I went back ayear ago to join the Catholic group in a community called Malcaba [...] / am very happy because we dance and praise God with songs and that I also like a lot [...] one follows him and afterwards, meditating, they also give us a lot of meditation, prayer. (Karuna)

In this previous sense, a human being can be spiritual but not have religion; can have religion, but not be religious, that is, or practice, but it is defined in a religion; In the end, it can be religious and have religion, but it can not be spiritual, that is, it is practiced but it cannot be understood.

The majority of the elders manifested the term God, understood as a superior force that was present in all the stages of his life that moves his own existence and leaves the responsibility of his own death as it was treated in the subject of death.

The presence of God in a conceptual sense is wrapped in its Christian origin, since most of the elders identified themselves in this religión. Therefore, the idea of spirituality is related to the same belief of a Christian God.

Elders use the concept of superior power with spirituality and religion. Spirituality in this section focuses on that higher power that is mentioned and that is throughout the existence and is manifested to the elder, even in the form of revelations that make him come out of difficult situations and that sustain him, as expressed by Madhavi who mentions that God spoke to him in the form of revelation to get her out of the alcoholism problems in which she lived. Or as Ura who mentions that God allows him to overcome situations in life and that he allows him to do what he likes and that gives him fullness. Or Sati who recognizes that God gave him strength to cope with a situation of learning how to work:

Well, experiences of these that have been terrible in my life and I have seen that God has been with me [...] for me it was a divine revelation one day I was very taken this, although you do not believe it would be very long to explain, I had a revelation from God, in which I communicated to AA they came to this house for me, they took me a lot. (Madhavi)

God is great, God gives us what we can endure, he does not give us more, if God allows me and I have the resources, I can continue traveling, that is fullness. (Ura)

Blessed be God who gave me strength, the learning how to work because I had never worked in my life, he supports me. (Sati)

The presence of God is manifested in some way in a sense of the elderly's own life that helps him to face negative experiences, integrating the satisfaction of his own life, the gratitude that is related to this life story, a sense of identity and in the end the fullness. The elder recognizes that God has accompanied him, that he provides him with strengths and mechanisms to live and motivates him by inspiring him the way forward, as Vani states that he thanked God for reaching his goals:

Blessed be my God after that road to travel so tremendous that still fills me with emotion, sometimes when I remember, but thank God and everything that happens I got to where I wanted to go because then my goal was to follow [...] but I think it was not so much alone, but it was also something divine that I decided to leave in order to get ahead. (Vani) 


\section{DISCUSSION}

Following the analysis in the hermeneutical circle, it is necessary to establish an understanding and interpretation of the previous results. Two concepts are central and stand out. Spirituality refers to a personal encounter of a human being with the intention of looking for a reason for his own existence, a connection of his interior with a search in aspects that he considers important for that existence, such as the end of life, death, the meaning of life or with something sacred or superior, like the concept of God, involves the transcendent term in the theological sense, something that surpasses $\mathrm{me}^{(14,24-25)}$.

Spirituality does not always involve practices in an established system, nor dogmas. When this organized belief system appears and with dogmas, moral, ethical principles, or, a series of practices to be developed, then religion is talked about.

As can be seen in the speeches, both spirituality and religion are present in the elderly, a sense of connection, this connection term closely related to the gerontotranscendence theory that speaks of connection, communion, connection with the cosmic. A cosmic connection is spirituality, a phenomenon that according to this theory increases in the last stage of life: old age $\mathrm{e}^{(12,26-27)}$.

Thus, the phenomenon of transcending the elder can be revealed in the existence of the old being as a being, not as an entity, because it may not be transcendent, but as a being, as a whole. The spiritual and religious phenomenon was revealed as self-care as part of the understanding of the elderly in its temporality and historicity, this understanding is the transcendence of himself.

This understanding as Heidegger mentions that "'being there" is understood in his being, in a more or less express way. It is peculiar to this being to be, with his being and his being, open to himself. The understanding of being is itself a "determination to be" of being there ${ }^{\prime \prime(6)}$. So that the Dasein or being-there old can exist to the extent that he does not allow himself to be enveloped in his daily events or in his life's happening. Each experience that has taken him to where he is is a manifestation of his being and shows the existence of the elderly, this manifestation is his spiritual and religious essence.

It is agreed that the idea of the spiritual and religious are merged to make way for an encounter with something sacred, becoming God the main sacred subject of the elderly and enveloping that sacred spirituality to explain the "why" of what it happens to the elderly and backing up in religion to respond to it ${ }^{(28)}$.

Spirituality is inherent to man in his sense of existential and that this leads him to seek explanations, that's when he looks for answers that he can find in something sacred, however, all comprehension goes beyond the practice.

Spirituality as such, increases in old age, as a result of a preparation to death, while religious practice takes a form of coping manifested in the same stage but mostly focused on functional losses. Not in so much, religious practices also help like confrontation to losses of social type, processes of mourning, a form to fill gaps that only God can fill with his concept of omnipresent and that gives peace and serenity to the elderly in front of this type of situations $s^{(14,29-31)}$.

Thus, spirituality and religiosity arise as part of caring and is an essential part of self-care, or as Heidegger would say, of selfconcern ${ }^{(7)}$. One speaks of the old being as a self-occupied being that makes use of "what is at hand"; in the face of falls and finitude this spiritual and religious sense always manifests itself; in some way it is conceived as finite and sees its possibilities of worrying about themselves, among them they throw their very possibilities in those forms of concern, the old being wondered as mentioned Heidegger expresses "he asks himself: what can I do? It enunciates a finitude. What this question touches in its most intimate interest makes clear a finitude in the most intimate of its essence"(32), and in the face of it rests on its spiritual and religious being.

This connection with a God is also reflected in the fact that some men say that they give their life and destiny to Him because they say they are aware that God will call them to another life, others make use of their blessings in their daily lives, always sharing that be superior to ones understanding of the world.

As an occupation of himself, it involves him, both in tradition and in his own being, Heidegger refers to the religious/spiritual life, that faith is the resolution to feel in the presence of God, religiosity is a matter of morality and ethics that gives fact ${ }^{(33)}$.

Religiosity and spirituality are a phenomenon to bring the old being to its finitude configures it in its facticity. By taking these resources as at hand understands that they are for a manifestation in the way of being to exist in the world, religious and spiritual manifestations were present in the speeches. God appears in a large part of the life of the elder as a source of wisdom.

The understanding of being an elder involves understanding what has already happened as having been, not as past, because the past would mean that it is no longer there and although it happened at a temporary moment in his life it still remains because he integrates it to understand himself as an elder, the present in the form of continuing care. He knows that he is an elderly person and that he needs to feel full and fulfilled, as he understands he is guided by caring.

This is part of its historical being and is framed in very specific contexts, in this case the Christian. To this Heidegger mentions that "The factual experience of life is historical. Christian religiosity lives temporality as such"(33).

Religion is determined by the social and historical context where the elder has been formed. It involves its relationship with the concepts, rites and beliefs corresponding to the teachings of a certain dogma.

Elderly man understands his future because he knows that he is a finite being whose corporality will end some day, he does not worry, but he is aware of it. Care continues integrating to continue what remains of their earthly life in the best way, with a full existence, a sense of existence where spirituality is present as part of their personal occupation, being spirituality and religiosity a reason of being same. Heidegger expresses care as "the original unit of the structure of the cure is temporality"(6).

These spiritual and religious resources configure the elderly and become part of that cure that has been liberated by the events of everyday life. Thus, spirituality and religiosity make him understand his being-been, his present and his becoming; this self-understanding of its temporality and its sense of being make the transcendent being.

There may be a connection between religion, religiosity and spirituality, because religion brings to the elder tools such as the ones mentioned that allow him through his practice to find a meaning to his existence, so that for him they all make up only one thing and can be experienced at different levels. They are 
a strength and a motivation that moves their spirit towards an understanding of what had been lived ${ }^{(24)}$.

This religiosity allows him to share his own experiences with other elders. Religion also behaves as a mechanism of socialization for the elderly that allows the manifestation of faith and the support of other brothers with whom they feel accompanied and motivated in their daily lives ${ }^{(34-35)}$.

Metaphysics leaves aside as what is outside of being and beyond, the old being in the past perceived as a "being at hand" the presence of a superior being, an understanding even of its finitude in the presence of something superior but that it is within itself because it finds its own meaning, that is a manifestation of "been", in the present it is occupied in the way of coexistence with others in some religious rituals and in the future it is expected as a finite being but that is the wait for a higher power that calls.

This is a conception in Christian theology that does not infer about the existence or not of a god, but that it manifests as the cultural horizon of the elder being of a community that has transmitted this belief to him. Some do not participate in rituals in a way that they consider that God is still out of it, religious institutions are not entirely for the elderly, but he has within himself an understanding of something sacred and the sacred is not necessarily a god, there spirituality conceived as part of a finite being. Heidegger alludes to taking the consideration of the divine: "in the last universal objective consideration, the total human experience must be reduced to concepts and also God must be studied as a real object"(33).

Frankl makes a comment respecting religion and spirituality, spirituality corresponds to the human being in his very existence, is something unconscious, as unconscious is his desire to approach something that gives reason or meaning, the true religion will be that which the practical person with firm conviction and understanding ${ }^{(36)}$.

The fact that being an elder has been conceived as finite does not mean that he has to deal with something as intimate as a type of spiritual occupation manifested by him. The elder expresses this spiritual occupation in the presence, the present and the future, even with a metaphysical connotation conceived in the Christian vision in the present speeches.

Metaphysics at this point manifests itself from a more human perspective, in the sense that its spiritual beliefs, even if founded on a Christian theology, reflect from within an internal metaphysical reach of the person, since they are reflected as part of themselves and their understanding. It manifests its link with the spiritual with a Christian concept of God. Some speeches sometimes show up without adhering to one's own rituals, but rather as a resource of what is at hand, God, being superior, is at hand; he does not abandon himself because then he would not be his own, he takes it as an element of support. The elders go to religious groups and not others, referring to having a communication with their God through their prayers.

The elderly makes use of this spirituality and religiosity as being at hand, not abandoning himself to direct his life, then he would fall into impropriety, but understanding that in truth he is part of himself and understands him as a resource. The awareness of God as expected also makes him have a conception of the finite of the mundane to expect a type of peace after the mundane and this has been transmitted to him by his beliefs that are part of his social history, here the nursing can do use of care interventions according to the context and characteristics of spirituality and religiosity, incorporating spiritual care to the assistance of the elderly.

For the elderly, "waiting tends to immortality as happiness, that is, toward union with God (theology)"(32), coming from its social history based on Christian theology as Heidegger reinforces, "in this way the totality of the entities, according to the Christian conscience of the world and of existence, is subdivided into God, Nature and man" $^{\prime \prime(32)}$. Thus, being an elderly reflects this historical consciousness where spirituality is at hand for him, which provides him with a part of his understanding as finite, as being for death and as a possibility for his own understanding.

The elderly reflect that they recognize that God is present in all their lives, some say that it is who guides their way, others that God has been their strength, that their achievements have had a divine help that they could not have accomplished alone. This transcendence or understanding of its temporality in spiritual care reflects in the elderly being a reason to feel full, satisfied and guided by a light that drives their sense of existence in personal historicity.

This returns to the initial question that unleashed the restlessness in being about its fullness, what Heidegger would call enlightenment ${ }^{(10)}$. This contemplation of oneself is an understanding of who he is as an elderly man, when he understands he is able to contemplate his temporality, he is able to contemplate all his abilities, possibilities, strengths and weaknesses and knows that his strengths are superior because he can guide them. Contemplating Heidegger's words is an understanding that allows him to manifest a meaning, the being is enlightened and shows its fullness in an express way ${ }^{(6)}$

This care, as Heidegger correctly mentions, is the source of understanding of being in order to reach its state of enlightenment, that state of maximum fullness that has endowed it with a sense of who it is in its being and, therefore, existing in the world as a spiritual being. In spiritual care, the nurse can address the history of each elder and incorporate their own meaning and experience of spirituality in order to take care of this human response in the elderly in various contexts, from the promotion of spirituality as part of mental health until the interventions with the hospitalized and institutionalized elder.

\section{Study limitations}

The present study presented limitations, among which the access to elderly in community environments stand out, since in the city where the study was conducted, there was access to groups of elderly people. However, it is necessary to access the elderly in other environments, in the same way the number of participants can be a limitation, which in turn is a reference source for future studies on the phenomenon studied.

\section{Contributions to Nursing}

The present study has as contributions to emphasize the concept of religiosity and spirituality as part of care because they are resources that the elderly make part of themselves as part of their care, so nursing should rescue the phenomenon of spiritual and religious care as part of the discipline. The nurse should value the ways that this phenomenon takes in the elderly and the importance that they give to find meaning in their lives, 
so that the knowledge provided to generate models of care and interventions focused on this way of seeing is prevailing. the religious and spiritual world for the elderly.

\section{FINAL CONSIDERATIONS}

Elderly being contemplates itself throughout its historicity, which makes it a historical being with experiences that frame its temporality in the world, so care is a part of its being and makes it exist, since it is the occupation of himself in the everyday.

A part of that care is spirituality and religiosity, both as phenomena unveiled before the question to be about its fullness. To be able to express that fullness, a deep introspection of the elder on himself was necessary, and thus his own understanding of spirituality and religiosity could be achieved as phenomena of care to face the everyday.

It shows that the elder is a spiritual being. This spirituality and religiosity are marked by the historical context and sustain the elder in his daily life helping him to find a sense of understanding of his life and therefore feel enlightened.

Spirituality and religiosity are part of care for nursing and their view from the phenomenology can contribute to punctualizing spiritual and religious care as a way of intervention towards the elderly. This study reaffirms the importance of the participation of the nurse in spiritual and religious care to promote transcendence that leads to the fullness of the elderly.

\section{REFERENCES}

1. Instituto Nacional de Estadística y Geografía (INEGI). Perfil sociodemográfico de adultos mayores [Internet]. Mexico: INEGl; 2014 [cited 2018 Dec 01]. Available from: http://internet.contenidos.inegi.org.mx/contenidos/productos/prod_serv/contenidos/espanol/bvinegi/productos/ censos/poblacion/2010/perfil_socio/adultos/702825056643.pdf

2. Mendoza-Núñez VM, Vivaldo-Martínez M, Martínez-Maldonado ML. Modelo comunitario de envejecimiento saludable enmarcado en la resiliencia y la generatividad. Rev Med Inst Mex Seguro Soc [Internet]. 2018 [cited 2018 Dec 17];56(Supl 1):S110-9. Available from: https:// www.medigraphic.com/cgi-bin/new/resumen.cgi?IDARTICULO=80636

3. Hemingway A, Jack E. Reducing social isolation and promoting well being in older people. Qual Ageing Older Adults. 2013;14(1):25-35. doi: 10.1108/14717791311311085

4. McCarthy VL, Bockweg A. The role of transcendence in a holistic view of successful aging: a concept analysis and model of transcendence in maturation and aging. J Holist Nurs. 2013;31(2):84-92. doi: 10.1177/0898010112463492

5. Guerrero-Castañeda RF, Prado ML, Kempfer SS, Vargas MGO. Momentos del proyecto de investigación fenomenológica. Index Enferm [Internet]. 2017 [cited 2018 Dec 01];26(1-2):67-71. Available from: http://scielo.isciii.es/scielo.php?script=sci_arttext\&pid=S1132-12962017000100015

6. Heidegger M. El ser y el tiempo. México: Fondo de Cultura Económica; 2015.

7. FrankI V. Psicoterapia y humanismo. México: Fondo de Cultura Económica; 2012.

8. Coward D. Self-Transcendence Theory. In: Alligood M, editors. Nursing theorists and their work. St. Louis: Elsevier/Mosby; 2014. p. 574-92.

9. Haugan G, Moksnes UK, Løhre A. Intrapersonal self-transcendence, meaning-in-life and nurse-patient interaction: powerful assets for quality of life in cognitively intact nursing-home patients. Scand J Caring Sci. 2016;30(4):790-801. doi: 10.1111/scs.12307

10. Heidegger M. Principios metafísicos de la lógica. Madrid: Síntesis; 2007.

11. Rajani F, Jawaid H. Theory of gerotranscendence: an analysis. Austin J Psychiatry Behav Sci [Internet] 2015 [cited 2019 Mar 11];2(1):1035. Available from: https://www.austinpublishinggroup.com/psychiatry-behavioral-sciences/fulltext/ajpbs-v2-id1035.php

12. Tornstam L. Maturing into gerotranscendence. J Transpers Psychol [Internet]. 2011 [cited 2016 Sept 22];43(2):166-80. Available from: http:// www.atpweb.org/jtparchive/trps-43-11-02-166.pdf

13. Ferreira AGC, Duarte TMM, Silva AF, Bezerra MR. Concepções de espiritualidade e religiosidade e a prática multiprofissional em cuidados paliativos. Rev Kairós [Internet]. 2015 [cited 2016 Sept 23];18(3):227-44. Available from: http://revistas.pucsp.br/index.php/kairos/article/ view/27054/19186

14. Chaves LJ, Gil CA. Concepções de idosos sobre espiritualidade relacionada ao envelhecimento e qualidade de vida. Ciênc Saúde Colet. 2015;20(12):3641-52. doi: 10.1590/1413-812320152012.19062014

15. Melo CF, Sampaio IS, Souza DLA, Pinto NS. Correlação entre religiosidade, espiritualidade e qualidade de vida: uma revisão de literatura. Estud Pesqui Psicol. 2015;15(2):447-64. doi: 10.12957/epp.2015.17650

16. Oliveira RM, Alves VP. A qualidade de vida dos idosos a partir da influência da religiosidade e da espiritualidade: cuidados prestados aos idosos institucionalizados em Caetité (BA). Rev Kairós [Internet]. 2014 [cited 2016 Sept 23];17(3):305-27. Available from: http://revistas. pucsp.br/index.php/kairos/article/view/23208/16770

17. Moreira H. Critérios e estratégias para garantir o rigor na pesquisa qualitativa. R Bras Ens Ci Tecno. 2018;11(1):405-24. doi: 10.3895/rbect. v11n1.6977

18. Tong A, Sainsbury P, Craig J. Consolidated criteria for reporting qualitative research (COREQ): a 32-item checklist for interviews and focus groups. Int J Qual Health Care. 2007;19(6):349-357. doi: 10.1093/intqhc/mzm042

19. Minayo MCS. Amostragem e saturação em pesquisa qualitativa: Consensos e controvérsias. Rev Pesqui Qualitativa [Internet]. 2017 [cited 
2019 Mar 09];5(7):1-12. Avaliable from: https://editora.sepq.org.br/index.php/rpq/article/view/82

20. Grove SK, Gray J, Burns N. Understanding nursing research: building an evidence-based practice. Philadelphia: Saunders; 2014.

21. Gil AC, Yamauchi NI. Elaboração do projeto na pesquisa fenomenológica em enfermagem. Rev Baiana Enferm 2014;26(3):565-73. doi: $10.18471 /$ rbe.v26i3.6613

22. Kempfer SS, Prado LM, Sebold LF, Balbinot J, Girondi R. Heidegger's hermenêutics as a data source in a phenomenologic study. In: Atas CIAIQ2015: Investigação Qualitativa em Saúde [Internet]. 2015 Aug 5-7 [cited 2016 Nov 01];1:108-12. Aracajú: Universidade Tiradentes; 2015. Available from: http://proceedings.ciaiq.org/index.php/ciaiq2015/article/viewFile/25/24

23. Mantzavinos C. O círculo hermenêutico: que problema é este? Tempo Soc. 2014;26(2):57-69. doi: 10.1590/S0103-20702014000200004

24. Zenevicz L, Moriguchi Y, Madureira VSF. The religiosity in the process of living getting old. Rev Esc Enferm USP. 2013;47(2):433-9. doi: $10.1590 /$ S0080-62342013000200023

25. Arévalo JAG. Aportes a la problemática ciencia-espiritualidad desde el budismo zen. Hallazgos. 2015;2(4):70-84. doi: 10.15332/ s1794-3841.2005.0004.05

26. White S. Gerotranscendence theory: a fresh look at positive aging. Engaging Aging [Internet]. 2015 [cited 2016 Sep 22];10(1):1-8. Available from: http://www.usccb.org/about/national-religious-retirement-office/upload/Engaging-Aging-Newsletter-Spring-2015.pdf

27. Jewell AJ. Tornstam's notion of gerotranscendence: Re-examining and questioning the theory. J Aging Stud. 2014;30:112-20. doi: 10.1016/j. jaging.2014.04.003

28. Gutz L, Camargo BV. Espiritualidade entre idosos mais velhos: um estudo de representações sociais. Rev Bras Geriatr Gerontol. 2013;16(4):793-804. doi: 10.1590/S1809-98232013000400013

29. Queiroz LCZ, Debella MC. Os benefícios da religiosidade na velhice. In: Impacto Científico e Social na Pesquisa. IX Mostra de Iniciação Científica e Extensão Comunitária e VIII Mostra de Pesquisa de Pós-Graduação da IMED. Passo Fundo: Editora IMED; 2016. p. 67-73. doi: 10.18256/978-85-99924-83-9-1

30. Rocha ACAL, Ciosak SI. Chronic disease in the elderly: spirituality and coping. Rev Esc Enferm USP. 2014;48(2):87-93. doi: 10.1590/ S0080-623420140000800014

31. Mukherjee SB. Spirituality and religion: elderly's perception and understanding [Internet]. Indian J Gerontol. 2016 [cited 2019 Mar 09];30(3):336-54. Available from: http://gerontologyindia.com/pdf/Vol-30-3.pdf

32. Heidegger M. Kant y el problema de la metafísica. México: Fondo de Cultura Económica; 2013.

33. Heidegger M. Fenomenologia da vida religiosa. Petrópolis: Vozes; 2010.

34. Reis LA, Menezes TMO. Religiosity and spirituality as resilience strategies among long-living older adults in their daily lives. Rev Bras Enferm [Internet]. 2017;70(4):761-6. [Thematic Edition "Good Practices: Fundamentals of care in Gerontological Nursing"] doi: 10.1590/0034-7167-2016-063035

35. Paula CLM, Santos EVL, Maia PCGGS, Gouveia Filho PS, Sousa MNA. Qualidade de vida de idosos participantes de um grupo de convivência no munícipio de São Mamede - PB. Rev Bras Educ Saúde. 2016;6(2):1-7. doi: 10.18378/rebes.v6i2.4018

36. FrankI V. La presencia ignorada de Dios. Psicoterapia y religión. Barcelona: Herder; 2011. 